\title{
Prevalence of iron deficiency anemia in Brazilian women of childbearing age: a systematic review with meta-analysis
}

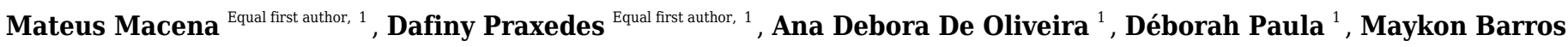 \\ ${ }^{1}$, André Silva Júnior ${ }^{2}$, Witiane Araújo ${ }^{1}$, Isabele Pureza ${ }^{2}$, Ingrid Sofia de Melo ${ }^{3}$, Nassib Bueno ${ }^{\text {Corresp. } 1,2}$ \\ 1 Universidade Federal de Alagoas, Maceió, Brazil \\ 2 Universidade Federal de São Paulo, São Paulo, Brazil \\ 3 Instituto Federal de Alagoas, Satuba, Brazil \\ Corresponding Author: Nassib Bueno \\ Email address: nassib.bueno@fanut.ufal.br
}

Background. Iron deficiency anemia (IDA) is among the most common micronutrient deficiencies in women of childbearing age and may affect children's development. Brazil has several national programs to tackle this condition, such as food fortification and supplementation for pregnant women, but IDA prevalence in this population has not been systematically reviewed. We sought to determine the prevalence of IDA in Brazilian women of childbearing age through a systematic review with metanalysis.

Methodology. A protocol was previously published on the PROSPERO platform under the code CRD42020200960. A panel of the National Council for Scientific and Technological Development (CNPq) approved the protocol of this study under the public call number 26/2019. The main databases searched were MEDLINE, Web of Science, Scopus, Lilacs, and SciELO. In gray literature, the Brazilian Digital Library of Theses and Dissertations and the annals of the Brazilian Congress of Epidemiology and the Brazilian Congress of Public Health were accessed. The search strategy involved terms related to the condition (IDA) and the age group of the population of interest (teenagers and adults). Studies that had assessed the prevalence of IDA in Brazilian women of childbearing age (10-49 years) were included. Three independent reviewers read all titles and abstracts and extracted data from the included studies. Random effects meta-analyses using the Freeman-Tukey arcsine transformation were carried out with prevalence data, and meta-regression was conducted to test for subgroup differences. The quality of the studies was assessed using the Newcastle-Ottawa Scale.

Results. From 21,210 unique records screened, 237 full-texts were retrieved, of which 91 were included in the qualitative synthesis, and 83 were included in the meta-analysis. The overall IDA prevalence was $25 \%$ (95\% Cl: [23; 28], 83 studies). The subgroup of studies that used random sampling showed a prevalence of $22 \%(95 \% \mathrm{Cl}$ : [17; 27], 22 studies), whereas in those with non-random sampling, the prevalence was $27 \%$ (95\% Cl: [23; 30], 61 studies), without significant differences between subgroups in the metaregression ( $P=0.13$ ). High prevalence of IDA were found in the subgroups of studies conducted in the North and Northeast regions (30\%; 95\%Cl: [24; 37]; 7 studies, and 30\%; 95\%Cl: [26; 34$] ; 27$ studies, respectively), in studies conducted with indigenous population (53\%; $95 \% \mathrm{Cl}$ : $[27 ; 78], 4$ studies), and with studies that had their collections after 2015 (28\%; 95\% Cl: [23; 34], 9 studies).

Conclusions. IDA in women of childbearing age remains a public health problem in Brazil, especially in the North and Northeast region. The national programs should be strengthened and more thoroughly supervised to decrease this condition nationally. 


\section{Prevalence of iron deficiency anemia in Brazilian}

2 women of childbearing age: a systematic review with

3 meta-analysis

4

5

6

7

8

9

10

11

13

14

15

16

17

18

19

20

21

22

23

24

25

26

27

28

29

30

31

32

33

34

35

36

Mateus Macena ${ }^{1}$, Dafiny Praxedes ${ }^{1}$, Ana Debora de Oliveira ${ }^{1}$, Déborah Paula ${ }^{1}$, Maykon Barros ${ }^{1}$, André Silva Júnior ${ }^{2}$, Witiane Araújo ${ }^{1}$, Isabele Pureza $^{2}$, Ingrid Sofia de Melo ${ }^{3}$, Nassib Bueno ${ }^{1,2}$

${ }^{1}$ Faculdade de Nutrição, Universidade Federal de Alagoas, Maceió, Alagoas, Brazil

${ }^{2}$ Escola Paulista de Medicina, Universidade Federal de São Paulo, São Paulo, São Paulo, Brazil

${ }^{3}$ Instituto Federal de Alagoas, Satuba, Alagoas, Brazil

Corresponding Author:

Nassib Bezerra Bueno ${ }^{1,2}$

Campus A.C. Simões Av. Lourival Melo Mota, Maceió, Alagoas, 57072-970, Brazil

Email address: nassib.bueno@fanut.ufal.br 


\section{Abstract}

38 Background. Iron deficiency anemia (IDA) is among the most common micronutrient

39 deficiencies in women of childbearing age and may affect children's development. Brazil has

40

41

42

43

44

45

46

47

48

49

50

51

52

53

54

55

56

57

58

59

60

61

62

63

64 several national programs to tackle this condition, such as food fortification and supplementation for pregnant women, but IDA prevalence in this population has not been systematically reviewed. We sought to determine the prevalence of IDA in Brazilian women of childbearing age through a systematic review with metanalysis.

Methodology. A protocol was previously published on the PROSPERO platform under the code CRD42020200960. A panel of the National Council for Scientific and Technological Development (CNPq) approved the protocol of this study under the public call number 26/2019. The main databases searched were MEDLINE, Web of Science, Scopus, Lilacs, and SciELO. In gray literature, the Brazilian Digital Library of Theses and Dissertations and the annals of the Brazilian Congress of Epidemiology and the Brazilian Congress of Public Health were accessed. The search strategy involved terms related to the condition (IDA) and the age group of the population of interest (teenagers and adults). Studies that had assessed the prevalence of IDA in Brazilian women of childbearing age (10-49 years) were included. Three independent reviewers read all titles and abstracts and extracted data from the included studies. Random effects metaanalyses using the Freeman-Tukey arcsine transformation were carried out with prevalence data, and meta-regression was conducted to test for subgroup differences. The quality of the studies was assessed using the Newcastle-Ottawa Scale.

Results. From 21,210 unique records screened, 237 full-texts were retrieved, of which 91 were included in the qualitative synthesis, and 83 were included in the meta-analysis. The overall IDA prevalence was 25\% (95\%CI: [23; 28], 83 studies). The subgroup of studies that used random sampling showed a prevalence of $22 \%(95 \% \mathrm{CI}$ : [17; 27], 22 studies), whereas in those with nonrandom sampling, the prevalence was 27\% (95\%CI: [23; 30], 61 studies), without significant differences between subgroups in the metaregression $(\mathrm{P}=0.13)$. High prevalence of IDA were found in the subgroups of studies conducted in the North and Northeast regions $(30 \%$; 95\%CI: [24; 37]; 7 studies, and 30\%; 95\%CI: [26; 34]; 27 studies, respectively), in studies conducted 
65 with indigenous population (53\%; 95\%CI: [27; 78], 4 studies), and with studies that had their 66 collections after 2015 (28\%; 95\%CI: [23; 34], 9 studies).

67 Conclusions. IDA in women of childbearing age remains a public health problem in Brazil, 68 especially in the North and Northeast region. The national programs should be strengthened and 69 more thoroughly supervised to decrease this condition nationally.

70

71

72

73

74

75

76

77

78

79

80

81

82

83

84

85

86

87 88

\section{Introduction}

The current focus of the "1000-day window of opportunity", from conception to 2 years of life, has driven nutritional interventions to improve overall health of the maternal-child duo, but it often ignores the preconception period (Dijkhuizen et al., 2019). The high nutritional burden on women was recognized by the United Nations Sustainable Development Goals, aiming to meet the nutritional needs of adolescent girls, as well as pregnant and lactating women, by 2030 (International Food Policy Research Institute, 2016). In order to optimize pregnancy outcomes and avoid harmful effects on the growth, development and health of the fetus and child, it is clear that the nutritional and health status of women of childbearing age should be the starting point. Optimizing the status of micronutrients in this public may be a more effective and preventive strategy than targeted interventions only during pregnancy (World Health Organization, 2009).

Micronutrient deficiencies in women of childbearing age, in addition to harming women's health, affect pregnancy outcomes, delaying intrauterine growth and child development (Grieger \& Clifton, 2014). Women are more vulnerable to micronutrient deficiencies due to their greater biological need and often due to the unequal distribution of food within the same household, by putting their families before their own needs (Darton-Hill, 2012). Among the most common micronutrient deficiencies in women is iron deficiency, which is the decrease in total body iron 
89 content (Muthayya et al., 2013). During their childbearing age, women are at increased risk of

90 iron deficiency due to blood loss from menstruation and often have insufficient dietary iron

91 intake to compensate for menstrual losses (Simpson et al., 2011). When the iron deficiency is

92 severe, it may compromise the erythropoiesis process, leading to a decrease in hemoglobin

93 concentration, a situation known as iron deficiency anemia (IDA), which affects a third of

94 women of childbearing age worldwide (Food and Agriculture Organization of The United

95 Nations, 2017). In Brazil, according to the National Survey on Demography and Health of

96 Children and Women (PNDS) carried out in 2006, which was the last survey carried out with the

97 objective of nationally evaluating women of childbearing age, the prevalence of IDA in this

98 group was 29.4\% (Brazil, 2009).

In order to tackle IDA, Brazil has several national programs, such as a food fortification program, which enriches wheat and corn flour with iron and folic acid, and was established in 2004 with the aim to decrease IDA (Brazil, 2002). In 2017, the Health Ministry of Brazil updated the fortification requirements, which is now ranges from $4 \mathrm{mg}$ to $9 \mathrm{mg}$ of ferrous sulphate or fumarate per 100 grams of flour (Brazil, 2017). A report from 2019 showed that only $61 \%$ of the flour samples analyzed showed adequate amounts of iron (Brazil, 2020). Together with the national fortification program is the National Iron Supplementation Program, established in 2005 , which aims to offer iron supplementation to children, pregnant women and women in the post-partum period (Brazil, 2005; Brazil, 2013). Hence, it would be expected that prevalence of IDA in Brazilian women of childbearing age should decrease throughout the years. essential for the development of national public policies and for monitoring the effectiveness of

111 existing programs. Thus, we aimed to determine, through a systematic review with meta- 
112 analysis, the prevalence of IDA in Brazilian women of childbearing age, and to analyze this

113 prevalence in different contexts.

114

\section{Materials and methods}

116

117

118

119

120

121

122

123

124

125

126

127

128

129

130

131

132

133

134

\section{Information sources}

Peer) reviewing PDF | (2021:10:67225:1:0:NEW 24 Dec 2021) 
Searches in MEDLINE, Web of Science (WOS), Scopus, Lilacs, SciELO databases were

136 carried out until September 24, 2021. In gray literature, the Brazilian Digital Library of Theses and Dissertations (http://bdtd.ibict.br) and the annals of the Brazilian Congress of Epidemiology and the Brazilian Congress of Public Health, both available on the ABRASCO website (www.abrasco.org.br) was accessed to obtain studies developed in the Brazilian population that were not published in indexed media in the aforementioned conventional databases.

\section{Search strategy}

For the construction of the search strategy, we used the acronym CoCoPop (condition, context and population). The search strategy involved terms related to the condition (IDA) and the age group of the population assessed (teenagers and adults). The context, which would include terms related to Brazil, was not used, as it limited the occurrences found in the databases. Two search strategies were used, one in English that had MeSH terms for MEDLINE and related free terms for Scopus and Web of Science, and another in Portuguese, using DeCS and Free Terms for LILACS and SciELO, in addition to the databases of gray literature. The following search was used in the MEDLINE database: (("iron"[MeSH Terms]) OR (iron deficiency anemia [MeSH Terms]) OR (ferritin [MeSH Terms])) AND ("prevalence"[MeSH Terms]) AND (("adolescent"[MeSH Terms]) OR ("adult"[MeSH Terms]) OR ("women"[MeSH Terms])).

\section{Data collection process}

The study selection process consisted of two stages: the title and abstract reading phase and the full-text reading phase. All occurrences were read by two independent authors (MM and DP). In addition, five other authors (AO, DP, MB, WA and IP) each read $20 \%$ of the total occurrences. Hence, at least three independent authors read all reports. Disagreements were 
157 resolved from another judgment carried out by NB. The data collection process consisted of

158 acquiring data derived from the eligibility criteria. For this purpose, an electronic spreadsheet

159 was used to organize the outcomes and additional variables collected. When cases of absence of

160 reported data were noticed, the authors of recent studies (2018-2021) included were contacted in

161 order to obtain more information.

162 Data items

163 The outcome evaluated was the prevalence of IDA. The complementary variables

164 collected were the following elements: name of the study authors; region and state of study; year

165 of study; type of study; age group; pregnant (yes/no); study context; method used to assess

166 hemoglobin levels; and total number of subjects analysed.

167 Effect measures

168 The prevalence of IDA was given as a percentage and was considered when hemoglobin

169 levels were below $12 \mathrm{~g} / \mathrm{dL}$ for non-pregnant women and below $11 \mathrm{~g} / \mathrm{dL}$ for pregnant women

170 (World Health Organization, 2011). When the prevalence of participants with IDA was not

171 available, it was calculated from the absolute frequencies of individuals with IDA and the total

172 sample evaluated.

173 Quality assessment of included studies

174 To assess the methodological quality of the studies, a spreadsheet was built based on the

175 Newcastle-Ottawa Scale, which is widely used for observational studies (Zeng et al., 2015), but

176 adapted for cross-sectional studies. This scale gives "stars" to studies that meet quality

177 assumptions. In the present analysis, 5 categories were evaluated, considering that only

178 prevalence studies were reviewed and that calculations of associations with risk measures will

179 not be considered in this study. 
181 of the chosen sample ( 2 stars in the case of representative samples of the population, with 182 random sampling, 1 star in the case of non-random sampling, 0 stars in the case of absence of 183 description for sampling); b) adequate sample size (1 star for justified and satisfactory sample 184 sizes, with sample size calculation, 0 stars for unjustified sample size); c) assessment of non185 respondents ( 1 star if there was an appreciation of non-respondents and indications that they do 186 not differ from respondents; 0 stars if non-respondents were not mentioned, or that they are 187 systematically different from respondents); d) diagnostic criteria (1 star if you used the 188 diagnostic criteria referenced in this protocol, 0 stars if you used other diagnostic criteria); e) measurement of biochemical markers ( 2 star if there was a complete and adequate description of the measurement methods of biochemical markers, such as intra-individual coefficient of variation tests, 1 star if reporting an adequate method but without coefficient of variation, 0 stars

192 if not there was a description of the method or if it was a method different from that provided for 193 in this protocol).

\section{Overall evidence quality}

195 The quality of the evidence was analyzed through adaptations of the method proposed by 196 the Grading of Recommendations Assessment, Developing and Evaluation (GRADE) (GRADE 197 working group, 2017). In the present analysis, this method was adapted for cross-sectional 198 studies. The quality of evidence was classified in three categories: high, moderate and low, based 199 on two criteria: limitations of the studies (quality assessment) and inconsistency of results 200 (heterogeneity). Only these criteria were used due to the inadequacy of analyzing the traditional 201 criteria "indirect evidence", "inaccuracy" and "publication bias" given the nature of the studies 202 included. 


\section{Data analysis}

204 Data analysis was based on a quantitative study of the variables. Stata v.12 software

205 (StataCorp, College Station, Texas) was used for this investigation, through the metaprop

206 command (Nyaga, Arbyn \& Aerts, 2014), with a DerSimonian and Laird random effects model

207 using the Freeman-Tukey arcsine transformation to stabilize the variances. The data analyzed

208 were the prevalence of IDA. Heterogeneity was assessed using the $\mathrm{I}^{2}$ statistic, being considered

209 high when the $\mathrm{I}^{2}$ is greater than $50 \%$. In addition, subgroup analyzes were performed by macro-

210 geographic region of Brazil where the study was conducted, age group, pregnant women

211 (yes/no), collection period and epidemiological context of collection. Finally, a meta-regression

212 was also performed with the prevalence of IDA as the dependent variable and the score obtained

213 by the Newcastle-Ottawa scale as the independent variable.

\section{Results}

\section{Study selection}

At total, 24,624 occurrences were identified in the evaluated databases. Of these, 237

were selected for full-text reading. Finally, 91 studies were included for the qualitative synthesis

218 and 83 for the meta-analysis. Details for the selection of studies can be seen in the flowchart in

219 Figure 1.

220 Studies characteristics

Of the 91 studies included, 48 (52.75\%) of them included samples with both age groups

222 (adolescents and adults). Fifty-three (58.24\%) studies were performed with samples from

223 pregnant women. By the Brazilian macrogeographic division, most studies were carried out

224 exclusively in the Southeast region $(n=34,37.36 \%)$ and a minority exclusively in the North 
225 region $(n=5,5.50 \%)$. The summary with the other characteristics of the included studies can be

226 seen in Table 1. The characteristics of each study can be seen in Supplementary Table 1.

\section{Quality assessment of included studies}

228

229

230

231

232

233

234

The result regarding the assessment of the quality of the included studies can be seen in Supplementary Table 2 and the sum of stars in this assessment is also shown in Supplementary

Table 1 . The median score obtained by the studies was 3 . The domains that presented the greatest inadequacies in the assessment according to the Newcastle Ottawa scale were related to the assessment of non-respondents $(n=59)$ and sample size $(n=58)$. The results of the metaregression showed no significant association between the prevalence of iron deficiency and the score obtained by the Newcastle Ottawa scale $(\beta=-1.7 \% ; 95 \% \mathrm{CI}:[-0.038 ; 0.003] ; \mathrm{p}=0.09)$.

\section{Result of syntheses}

The quantitative assessment of the 83 studies included in the meta-analysis can be seen in Table 2. Eight studies did not participate in the quantitative analyzes due to inconsistency in the data regarding the prevalence of IDA $[29,30,37,51,53,58,85,104]$, which could interfere with our final results. The prevalence of IDA in all studies included in this analysis was $25 \%(95 \% \mathrm{CI}=$ $23 ; 28 ; I^{2}=97.94 ; 83$ studies, 57981 participants). The subgroup of studies that used random sampling showed a prevalence of 22\% (95\%CI: [17; 27], 22 studies) whereas in those with nonrandom sampling the prevalence was $27 \%(95 \% \mathrm{CI}$ : [23; 30], 61 studies), without significant differences between subgroups in the meta-regression $(\beta=-5 \%$; 95\%CI: $[-13.2 ; 1.7] ; \mathrm{P}=0.13)$. Among the macro-geographic regions of Brazil, the North and Northeast regions showed the highest prevalence, $30 \%(95 \% \mathrm{CI}=24 ; 37 ; 7$ studies; 5328 participants $)$ and $30 \%(95 \% \mathrm{CI}=$ 26; 34; 27 studies; 19087 participants), respectively. Meta-regression analysis revealed that 
247 macro-geographic region was a significant predictor of the IDA prevalence $(\beta=-2.8 \%$; $95 \% \mathrm{CI}$ :

$248 \quad[-5.1 ;-0.4] ; \mathrm{P}=0.01)$.

249 Other subgroups that showed high prevalence of IDA were those with studies with only 250 adult women (26\%; 95\%CI:[21; 31]; 16 studies; 8091 participants); which included samples of 251 pregnant and non-pregnant women together (42\%; 95\%CI:[17; 69]; 3 studies; 1018 participants); 252 with indigenous people (53\%; 95\%CI:[27; 78]; 4 studies; 923 participants); conducted in the 253 hospital context (36\%; 95\%CI:[31; 40]; 13 studies; 7753 participants); and studies that had their 254 collections after 2015 (28\%; 95\%CI:[23; 34]; 9 studies; 7291 participants).

\section{Certainty of evidence}

256

Considering the limitations of the studies included in this review and the inconsistency of 257 the results, the quality of evidence was considered very low (Table 3).

\section{Discussion}

259

260

261

262

263

264

265

266

267

268

269

This is the first systematic review to pool the prevalence of IDA in Brazilian women of childbearing age. IDA is estimated to affect about a third of women of childbearing age in the world (World Health Organization, 2021a). The regions of the globe in which this prevalence is higher are Sub-Saharan Africa, South Asia, the Caribbean and Oceania (Kassebaum et al., 2014). Despite not being part of the regions mentioned, the results of the present study indicate a prevalence of $25 \%$ for this condition in Brazil. Such prevalence is considered high, and it was even higher among women in the North and Northeast regions of the country. Furthermore, it is noteworthy that overall, the quality of the included studies was low. To overcome this limitation, we conducted subgroup analyses and meta-regression analysis. Nevertheless, the prevalence of IDA did not show significant differences between studies that used a random sampling approach versus those with non-random sampling. 
271 considered a public health problem when it is above $5 \%$, which gives a degree of significance to

272 the respective severity of this prevalence in the present study (World Health Organization, 2011).

273 Thus, all the grouped prevalence of IDA found in this review fit the classification established by

274 the WHO, ranging from a problem of mild significance (18\% of adolescents) to severe $(53 \%$ of

275 indigenous women). In addition, our findings show a higher prevalence than indicated by the

276 WHO survey for Brazil in 2019 (16.1\% for non-pregnant women and 19.1\% for pregnant

277 women) [World Health Organization, 2021b; World Health Organization, 2021c].

278 Petry et al. (2016) aimed to carry out, through a systematic review, a survey of the

279 prevalence of IDA in women of childbearing age in countries with low, medium and high human 280 development index. Countries such as Bangladesh (2011/2012), Cameroon (2012), Côte d'Ivoire 281 (2007), Mongolia (2010) and Iraq (2011) showed prevalence (18.5 to 28.6\%) similar to that 282 found in our meta-analysis [115]. We are not aware of a systematic review that has assessed this 283 prevalence in women of childbearing age in Brazil. However, this type of investigation has 284 already been carried out in children under the age of five. Systematic reviews with meta-analyses 285 by Silveira et al. (2021) and Ferreira et al. (2021) show that compared to older studies, the 286 prevalence of IDA in children under five years has been decreasing (Ferreira et al., 2021;

287 Silveira et al., 2021). Reinforcing this, according to the Ministry of Health of Brazil, referring to 288 the National Study on Food and Child Nutrition, the prevalence of anemia in Brazilian children 289 has reduced by half in the last 13 years (Brazil, 2020b). These notes are different from what 290 seems to be happening with women of childbearing age when comparing the studies by the data 291 collection period in this meta-analysis. 
Survey conducted between 2013 and 2014 with women aged over 18 years, the macro-regions of

294 Brazil that had the lowest prevalence of iron deficiency anemia were the southern regions $(9.0 \%)$

295 and Midwest (7.9\%) (Machado et al., 2019). In our study with women of childbearing age, the

296 lowest prevalence was found in the South (20\%) and Southeast (21\%) regions. However, in

297 relation to the highest prevalence, both the National Health Survey (2013-2014) and our analyzes

298 highlight the North (14.6\% vs. 30\%, respectively) and Northeast (15.7\% vs. 30\%, respectively)

299 regions (Machado et al., 2019).

300 Such differences between the macro-regions within Brazil can be explained by the

301 evident social inequality and distinct development between the macro-geographic regions,

302 making the South-Southeast two regions with greater development, providing a better quality of

303 life, and the opposite generates higher prevalence in the North-Northeast regions (Ferreira Filho

$304 \&$ Horridge, 2006). The root of this inequality among Brazilian macro-regions is complex and

305 involves several factors. Briefly, the South and Southeast regions of Brazil have historically

306 received more incentives from Brazilian governments, especially regarding industrialization and

307 allocation of foreigner's investments, which contributed to the social development of these

308 regions. On the other hand, the North and Northeast region did not go through an

309 industrialization process and remained with economic activities with lower aggregated value

310 (Monteiro-Neto, 2014).

311 Paying attention to risk factors for IDA implies improving the quality of life of women of

312 childbearing age, since this nutritional deficiency has already been shown to be associated with

313 cognitive impairment and neuropsychiatric disorders increasingly common in children and

314 adolescents, such as autism and anxiety disorder (Islam et al., 2018). In adolescence, it has an 
315 impact on physical and mental development, such as cognitive impairment, impairment of the 316 proper functioning of the respiratory system, causing fatigue, fatigue and weakness, which can

317 be considered a trigger for weight gain due to the lack of willingness to performing physical 318 exercise (Garzon et al., 2020; World Health Organization, 2001). Furthermore, pregnant women 319 who start this physiological period with IDA have higher risks of maternal and perinatal death, 320 premature birth, low birth weight and infant morbidity (Batista Filho, De Souza \& Bresani, 2008; 321 Lício, Fávaro \& Chaves, 2016), in addition to impacts during pregnancy itself, such as emotional 322 instability, pre-eclampsia, cardiovascular and immune function changes, and lower physical and 323 mental performance (Garzon et al., 2020). Given the relevance of this public health problem to the lives of individuals, the Brazilian government implemented in 2005 the National Iron Supplementation Program, which consists 326 of: prophylactic iron supplementation for specific population groups (for all children aged 0 to 6 327 months age, pregnant women starting prenatal care until the third month postpartum); 328 fortification of food for children with powdered micronutrients; promotion of adequate and healthy diet to increase consumption of iron-rich foods; and the mandatory fortification of corn and wheat flour with iron and folic acid (Brazil, 2013). The studies conducted by Araújo et al. (2013) and Fujimori et al. (2011) indirectly showed that such flour fortification was able to 332 reduce the prevalence of iron deficiency anemia in pregnant women (Araújo et al., 2013; 333 Fujimori et al., 2011). However, we have not identified any studies that have evaluated this 334 strategy in another population group for the interest of this systematic review. This systematic review has some limitations that may influence our conclusions. First, we 336 highlight the wide variation between the sizes and quality of the included studies, which possibly 337 contributed to the finding of the high heterogeneity identified in the meta-analyses, as well as the 
338 very low quality of evidence. Still, we tried to explore via subgroup and meta-regression analysis

339 the impact of the study quality in our results. In addition, the discrepancy in the number of

340 studies between Brazilian macro-geographic regions is highlighted, which can make the

341 comparison between them uneven. We also highlight the small number of studies aiming at

342 evaluating indigenous populations, which may have made the pooled prevalence of this sample

343 unrealistic in our analysis. Finally, we highlight the need for further studies to update the

344 assessment of the prevalence of IDA in women of childbearing age, since few studies were

345 conducted after 2015 and it was difficult to conduct a time-series comparison to highlight

346 possible temporal changes in the prevalence of this nutritional deficiency.

\section{Conclusions}

348 IDA in women of childbearing age remains a public health problem in Brazil, and the

349 population in the North and Northeast of the country need greater care for the prevention and 350 treatment of this condition. Thus, greater efforts by the Brazilian government are needed to 351 strengthen and better supervise the national programs of iron supplementation and fortification.

352

353

354

355

356

357

358

\section{References}

Américo SC, Ferraz FB. 2011. Prevalência de anemias em gestantes do município de Campo Mourão - PR entre os períodos de 2005 a 2008. Semina: Ciências Biológicas e da Saúde 32: 59-68. DOI 10.5433/1679-0367.2011v32n1p59.

Araf LN, Pereira CA, Machado RS, Raguza D, Kawakami E. 2010. Helicobacter pylori and iron-deficiency anemia in adolescents in Brazil. Journal of Pediatric Gastroenterology and Nutrition 51:477-480. DOI: 10.1097/MPG.0b013e3181d40cd7.

Araújo CR. 2012. Determinantes da anemia em mães e filhos no Brasil. PhD. Dissertation, Universidade de São Paulo. 
362 Araújo CR, Uchimura TT, Fujimori E, Nishida FS, Veloso GB, Szarfarc SC. 2013.

363 Hemoglobin levels and prevalence of anemia in pregnant women assisted in primary health

364 care services, before and after fortification of flour. Revista Brasileira de Epidemiologia 16:

365 535-45. DOI: 10.1590/S1415-790X2013000200027.

366 Arruda IK. 1990. Prevalência de anemia em gestantes de baixa renda: algumas variáveis

367 associadas e sua repercussão no récem-nascido. MSc. Thesis, Universidade Federal de

368 Pernambuco.

369 Arruda IK. 1997. Deficiência de ferro, folato e anemia em gestantes atendidas no Instituto

370 Materno Infantil de Pernambuco: magnitude, fatores de risco e implicações nos seus

371 conceptos. PhD. Dissertation, Universidade Federal de Pernambuco.

372 Bagni US, Luiz RR, Da Veiga GV. 2013. Overweight is associated with low hemoglobin

373 levels in adolescent girls. Obesity Research \& Clinical Practice 7:e218-e229. DOI:

$374 \quad 10.1016 /$ j.orcp.2011.12.004.

375 Batista Filho M, Romani SAM. 2002. Alimentação, nutrição e saúde no Estado de

376 Pernambuco: espacialização e fatores sócio-econômicos. Recife: Série de Publicações

377 Científicas do Instituto Materno-Infantil de Pernambuco.

378 Batista Filho M, De Souza AI, Bresani CC. 2008. Anemia as a public health problem: the 379 current situation. Revista Ciência \& Saúde Coletiva 13: 1917-1922. DOI: 10.1590/s1413-

$380 \quad 81232008000600027$

381 Bezerra AG, Leal VS, De Lira PI, Oliveira JS, Costa EC, De Menezes RC, De Siqueira e 382 Campos FA, De Andrade MI. 2018. Anemia and associated factors in women at reproductive 383 age in a Brazilian Northeastern municipality. Revista Brasileira de Epidemiologia 384 21:e180001. DOI: 10.1590/1980-54972018000. 
385 Borges MC, Buffarini R, Santos RV, Cardoso AM, Welch JR, Garnelo L, Coimbra Jr CE, 386 Horta BL. 2016. Anemia among indigenous women in Brazil: findings from the First 387 National Survey of Indigenous People's Health and Nutrition. BMC Women's Health 16:7 388 DOI: $10.1186 / \mathrm{s} 12905-016-0287-5$.

389 Brazil. 2002. Resolução-RDC No 344, de 13 de Dezembro de 2002. Available at 390 https://bvsms.saude.gov.br/bvs/saudelegis/anvisa/2002/rdc0344_13_12_2002.html (accessed $391 \quad 13$ October 2021).

392 Brazil. 2005. Portaria No 730 de 13 de Maio de 2005. Available at 393 https://bvsms.saude.gov.br/bvs/saudelegis/gm/2005/prt0730_13_05_2005.html (acessed 13 394 October 2021). Brazil. 2009. Centro Brasileiro de Análise e Planejamento. Pesquisa Nacional de Demografia 396 e Saúde da Criança e da Mulher - PNDS 2006: dimensões do processo reprodutivo e da 397 saúde da criança. Brasília: Ministério da Saúde. Brazil. 2013. Programa Nacional de Suplementação de Ferro: Manual de Condutas Gerais. 399 Brasília: Ministério da Saúde. Brazil. 2017. Resolução-RDC Nº 150, de 13 de Abril de 2017. Available at 401 http://antigo.anvisa.gov.br/documents/10181/2718376/RDC_150_2017_.pdf/a873d3b9-3e93402 49f3-b6c5-0f45aefcd348 (accessed 13 October 2021). Brazil. 2020a. Relatório do Monitoramento da Fortificação de Farinhas de Trigo e Milho 404 com Ferro e Ácido Fólico. Brasília: Agência Nacional de Vigilância Sanitária. 
405 Brazil. 2020b. Brasil reduz anemia e carência de vitamina A em crianças de até cinco anos.

406 Ministério da Saúde: Governo Federal. Available at https://www.gov.br/saude/pt-

407 br/assuntos/noticias/brasil-reduz-anemia-e-carencia-de-vitamina-a-em-criancas-de-ate-cinco-

408 anos\#: : :text=A\%20doen\%C3\%A7a\%20recuou\%20de \%2020,predomin\%C3\%A2ncia\%20de

$409 \quad \% 2018 \% 2 \mathrm{C} 9 \% 25$ (accessed 05 October 2021).

410 Bresan D, De Oliveira GE, Ávalos TV, Leite MS, Pontes ER. 2018. Características maternas

411 e peso ao nascer de crianças indígenas terena residentes em aldeias urbanas de Campo

412 Grande, MS. $12^{\circ}$ Congresso Brasileiro de Saúde Coletiva. Available at

413 http://www.saudecoletiva.org.br/programacao/exibe_trabalho.php?id_trabalho=24024\&id_ati

414 vidade=2964\&tipo=\#topo. $($ accessed 06 October 2021).

415 Bresani CC, De Souza AI, Batista Filho M, Figueiroa JN. 2007. Anemia and iron deficiency

416 in pregnant women: disagreements among the results of a cross-sectional study. Revista

417 Brasileira de Saúde Materno Infantil 7: S15-S21. DOI: 10.1590/S1519-

$418 \quad 38292007000600002$.

419 Carvalho OM, Vidal CR, Freitas I, Moura RC, Castro B, Caravalho FH, Lima HM, De Lima

420 LR. 2017. Aspectos clínicos dos óbitos maternos em maternidade do nordeste do Brasil, 2010

421 a 2015. X Congresso Brasileiro de Epidemiologia. Available at

422 https://proceedings.science/epi/trabalhos/aspectos-clinicos-dos-obitos-maternos-em-

423 maternidade-do-nordeste-do-brasil-2010-a-2015?lang=pt-br (accessed 06 October 2021).

424 Cavalcanti DS, De Vasconcelos PN, Muniz VM, Dos Santos NF, Osório MM. 2014. Iron

425 intake and its association with iron-deficiency anemia in agricultural workers' families from

426 the Zona da Mata of Pernambuco, Brazil. Revista de Nutrição 27: 217-227. DOI:

$427 \quad 10.1590 / 1415-52732014000200008$. 
428 Cavalcanti RA, Diniz AS, Arruda IK. 2019. Concentrations of intra-erythrocyte folate, serum 429 vitamin B12, and hemoglobin in women of childbearing age and associated factors. Journal $430 \quad$ of the American College of Nutrition 38:739-45. DOI: 10.1080/07315724.2019.1592725.

431 Cintra SM. 2018. Prevalência de anemia e suas relações entre mães e filhos pré-escolares em 432 um município de elevado Índice de Desenvolvimento Humano. PhD. Dissertation, 433 Universidade de São Paulo.

434 Clemente HA. 2019. Tendência temporal da anemia e seus fatores associados 435 em mulheres em idade reprodutiva do estado de Pernambuco. PhD. Dissertation, $436 \quad$ Universidade Federal de Pernambuco. 2019.

437 Coelho PB. 2011. Determinantes da morbimortalidade perinatal na gravidez gemelar. MSc. 438 Thesis, Fundação Oswaldo Cruz.

439 Côrtes MH. 2006. Impacto da fortificação das farinhas de trigo e de milho com ferro nos 440 níveis de hemoglobina das gestantes atendidas pelo pré-natal do Hospital Universitário de 441 Brasília/DF. MSc. Thesis, Universidade de Brasília.

442 Da Costa NF, Schtscherbyna A, Soares EA, Ribeiro BG. 2013. Disordered eating among 443 adolescent female swimmers: Dietary, biochemical, and body composition factors. Nutrition 444 29: 172-177. DOI: 10.1016/j.nut.2012.06.007.

445 Da Silva RM. 2015. Determinantes da anemia em gestantes usuárias do Programa de Saúde 446 da Família do município de Santo Antônio de Jesus - Bahia. MSc. Thesis, Universidade 447 Estadual de Feira de Santana.

448 Dal Pizzol TS, Giugliani ER, Mengue SS. 2009. Association between iron supplementation 449 during pregnancy and prematurity, low birth weight, and very low birth weight. Cadernos de $450 \quad$ Saúde Pública 25: 160-168. DOI: S0102-311X2009000100017. 
451 Dani C, Rosseto S, Castro SM, Wagner SC. 2008. Anemia prevalence and nutritional

452 deficiencies, through different laboratory parameters, in pregnant women assisted in two

453 services of public health in Rio Grande do Sul. Revista Brasileira de Análises Clínicas

$454 \quad$ 40:171-175.

455 Darton-Hill I. 2012. Global burden and significance of multiple micronutrient deficiencies in 456 pregnancy. Nestlé Nutrition Institute Workshop Series 70: 49-60. DOI: 10.1159/000337421.

457 De Camargo RM, Espinosa MM, Pereira SF, Schirmer J. 2013. Prevalência de anemia e 458 deficiência de ferro: relação com índice de massa corporal em gestantes do Centro-Oeste do 459 Brasil. Medicina (Ribeirão Preto) 46:118-127. DOI: 10.11606/issn.2176-7262.v46i2p118$460 \quad 127$.

461 De Carli E, Dias GC, Morimoto JM, Marchioni DM, Colli C. 2018. Dietary iron 462 bioavailability: Agreement between estimation methods and association with serum ferritin 463 concentrations in women of childbearing age. Nutrients 10:650. DOI: 10.3390/nu10050650. 464 De Castro MM, Corona LP, Pascoal LB, Rodrigues BL, Ayrizono ML, Coy CS, Leal RF, 465 Milanski M. 2019. Impaired nutritional status in outpatients in remission or with active 466 Crohn's disease - classified by objective endoscopic and imaging assessments. Clinical 467 Nutrition ESPEN 33:60-65. DOI: 10.1016/j.clnesp.2019.07.006.

468 De França MG. 2006. Prevalência de anemia ferropriva em adolescentes da "Vila Princesa" 469 lixão em Porto Velho - RO. MSc. Thesis, Universidade de Brasília.

470 De Oliveira AC, De Barros AM, Ferreira RC. 2015. Risk factors associated among anemia in 471 pregnancy women of network public health of a capital of Brazil Northeastern. Revista 472 Brasileira de Ginecologia e Obstetrícia 37:505-511. DOI: 10.1590/SO100$473 \quad 720320150005400$. 
474 De Sá SA, Willner E, Pereira TA, De Souza VR, Boaventura GT, De Azeredo VB. 2015.

475 Anemia in pregnancy: impact on weight and in the development of anemia in newborn.

$476 \quad$ Nutricion Hospitalaria 32:2071-2079. DOI: 10.3305/nh.2015.32.5.9186.

477 De Souza JA. 2011. Prevalência de anemia e fatores associados nas aldeias Xavante de

478 Pimentel Barbosa e Etênhiritipá, Mato Grosso, Brasil. MSc. Thesis, Fundação Oswaldo Cruz.

479 Dell Agnolo CM. 2009. Gravidez após cirurgia bariátrica: implicações para a mãe e o recém480 nascido. MSc. Thesis, Universidade Estadual de Maringá.

481 Demétrio F, Teles-Santos CA, Dos Santos DB. 2017. Food insecurity, prenatal care and other 482 anemia determinants in pregnant women from the NISAMI Cohort, Brazil: hierarchical 483 model concept. Revista Brasileira de Ginecologia e Obstetrícia 39:384-396. DOI: 10.1055/s$484 \quad 0037-1604093$.

485 Dijkhuizen MA, Greffeille V, Roos N, Berger J, Wieringa FT. 2019. Interventions to 486 improve micronutrient status of women of reproductive age in southeast asia: a narrative 487 review on what works, what might work, and what doesn't work. Maternal and Child Health 488 Journal 23:18-28. DOI: 10.1007/s10995-018-2637-4.

489 Dos Santos MT, Costa KM, Bezerra IM, Santos EF, Szarfarc SC, Pereira MJ, De Abreu LC, 490 Venancio DP. 2020. Anemia and iron deficiency in primigent parturients in a municipality of 491 Brazilian west Amazon. Medicine (Baltimore) 99:e22909. DOI:

$492 \quad$ 10.1097/MD.0000000000022909.

493 Dos Santos VC, Loureiro FA, Moraes CV, Ferreira AA, Welch JR, Coimbra Jr CE. 2018. 494 Excesso de peso e anemia em mulheres adultas xavante em idade fértil (Mato Grosso). $12^{\circ}$ 495 Congresso Brasileiro de Saúde Coletiva. Available at 
496 http://www.saudecoletiva.org.br/programacao/exibe_trabalho.php?id_trabalho=22062\&id_ati

$497 \quad$ vidade $=2964 \&$ tipo $=\#$ topo $($ accessed 07 October 2021).

498 Einloft AB, Vitor CF, Sant'Ana LF, Priore SE, Franceschini SC. 2010. Effect of parasitic

499 infection and maternal anemia on the birth weight of children in Viçosa, MG. Revista Médica $500 \quad$ de Minas Gerais 20:317-322.

501 Fabian C, Olinto MT, Dias-da-Costa JS, Bairros F, Nácul LC. 2007. Anemia prevalence and 502 associated factors among adult women in São Leopoldo, Rio Grande do Sul, Brazil.

503 Cadernos de Saúde Pública. 25:1119-1205. DOI: 10.1590/S0102-311X2007000500021.

504 Fávaro TR. 2011 Perfil nutricional da população indígena Xokuru de Ororubá, Pernambuco, 505 Brasil. PhD. Dissertation, Fundação Oswaldo Crus.

506 Ferreira MR, Souza W, Perez EP, Lapa T, Carvalho AB, Furtado A, Coutinho HB, Wakelin 507 D. 1998. Intestinal helminthiasis and anaemia in youngsters from Matriz da Luz, district of 508 Säo Lourenço da Mata, State of Pernambuco, Brazil. Memórias do Instituto Oswaldo Cruz 509 93: 289-293. DOI: 10.1590/S0074-02761998000300002.

510 Ferreira MU, Silva-Nunes M, Bertolino CN, Malafronte RS, Muniz PT, Cardoso MA. 2007. 511 Anemia and iron deficiency in school children, adolescents, and adults: A community-based 512 study in rural Amazonia. American Journal of Public Health 97:237-239. DOI:

$513 \quad 10.2105 /$ AJPH.2005.078121.

514 Ferreira HS, Moura FA, Cabral Júnior CR. 2008. Prevalence and factors associated with 515 anemia in pregnant women from the semiarid region of Alagoas, Brazil. Revista Brasileira 516 de Ginecologia e Obstetrícia 30:445-51. DOI: 10.1590/S0100-72032008000900004.

517 Ferreira LB. 2016. Associação do estado nutricional e da saúde da gestante com a doação de 518 leite materno. MSc. Thesis, Universidade Federal de Minas Gerais. 
519 Ferreira HS, Vieira RC, Livramento AR, Dourado BL, Silva GF, Calheiros MS. 2021.

520 Prevalence of anaemia in Brazilian children in different epidemiological scenarios: an

$521 \quad$ updated meta-analysis. Public Health Nutrition 24:2171-2184. DOI:

$522 \quad 10.1017 / \mathrm{S} 1368980019005287$

523 Ferreira Filho JB, Horridge MJ. 2006. Economic integration, poverty and regional inequality

524 in Brazil. Revista Brasileira de Economia 60:363-387. DOI: 10.1590/S0034-

$525 \quad 71402006000400003$

526 Food and Agriculture Organization of The United Nations. 2017. International Fund for

527 Agricultural Development, United Nations Children's Fund, World Food Programme, World

528 Health Organization. The state of food security and nutrition in the world 2017. Building

529 resilience for peace and food security. Rome: Food and Agriculture Organization of the

$530 \quad$ United Nations.

531 Frota MT. 2013. Prevalência e fatores associados à anemia em crianças e mulheres atendidas 532 pela estratégia de Saúde da Família no Maranhão. PhD. Dissertatin, Universidade de São

533 Paulo. 2013.

534 Fujimori E, Szarfarc SC, De Oliveira IM. 1996. Prevalence of anemia and iron-deficiency in 535 female teenagers - Taboão da Serra, SP, Brazil. Revista Latino-Americana de Enfermagem

536 4:49-63. DOI: 10.1590/S0104-11691996000300005.

537 Fujimori E, De Oliveira IM, Cassana LM, Szarfarc SC. 1999. Iron nutritional status in 538 pregnant adolescents, Säo Paulo, Brazil. Archivos Latinoamericanos de Nutrición 49:8-12.

539 Fujimori E, Sato AP, Szarfarc SC, Da Veiga GV, De Oliveira VA, Colli C, Moreira-Araújo

540 RS, De Arruda IK, Uchimura TT, Brunken GS, Yuyama LK, Muniz PT, Priore SE,

541 Tsunechiro MA, Frazão AG, Passoni CR, Araújo CR. 2011. Anemia em gestantes brasileiras 
542 antes e após a fortificação das farinhas com ferro. Revista de Saúde Pública 45:1027-1035.

543 DOI: $10.1590 / \mathrm{S} 0034-89102011005000078$.

544 Garzon S, Cacciato PM, Certelli C, Salvaggio C, Magliarditi M, Rizzo G. 2020. Iron

545 deficiency anemia in pregnancy: novel approaches for an old problem. Oman Medical

$546 \quad$ Journal. 35: e166. DOI: 10.5001/omj.2020.108

547 GRADE working group. 2017. The Grading of Recommendations Assessment, Development

548 and Evaluation. Available at: http://www.gradeworkinggroup.org (accessed 02 October

$549 \quad 2021)$

550 Grieger JA, Clifton VL. 2014. A review of the impact of dietary intakes in human pregnancy

$551 \quad$ on infant birthweight. Nutrients 7:153-178. DOI: 10.3390/nu7010153.

552 Guerra EM, Barretto OC, Vaz AJ, Silveira MB. 1990. The prevalence of anemia in first

553 consultation pregnant women of health centers in a metropolitan area, Brazil. Revista de

$554 \quad$ Saúde Pública 24:380-386. DOI: 10.1590/S0034-89101990000500005.

555 Hirata AM, Braga JA, Vitalle MS, Amancio OM. 2017. Effect of the Brazilian iron

556 fortification of wheat and corn flour on the nutritional iron status in adolescents, 6 years after

557 its implementation. Nutrire 42:11 DOI: 10.1186/s41110-017-0035-0

558 International Food Policy Research Institute. 2016. Global Nutrition Report 2016: From

559 Promise to Impact: Ending Malnutrition by 2030. International Food Policy Research

$560 \quad$ Institute; Washington, DC, USA.

561 Instituto Nacional de Alimentação e Nutrição (Brasil). 1998. Instituto Materno Infantil de

562 Pernambuco, Universidade de Pernambuco. Secretaria de Estado de Saúde de Pernambuco. II

563 Pesquisa Estadual de Saúde e Nutrição: saúde, nutrição, alimentação e condições socio-

564 econômicas no estado de Pernambuco. Recife; SES/PE, Livrotab. 
565 Islam K, Seth S, Saha S, Roy A, Das R, Datta AK. 2018. A study on association of iron 566 deficiency with attention deficit hyperactivity disorder in a tertiary care center. Indian 567 Journal of Psychiatry 60:131-134. DOI: 10.4103/psychiatry.IndianJPsychiatry_197_17

568 Kassebaum NJ, Jasrasaria R, Naghavi M, Wulf SK, Johns N, Lozano R, Regan M, 569 Weatherall D, Chou DP, Eisele TP, Flaxman SR, Pullan RL, Brooker SJ, Murray CJ. 2014. A 570 systematic analysis of global anemia burden from 1990 to 2010. Blood 123:615-624. DOI: $571 \quad$ 10.1182/blood-2013-06-508325.

572 Leite MS. 1998. Avaliação do estado nutricional da população Xavante de avaliação do 573 estado nutricional da população Xavante de São José, Terra Indígena Sangradouro - Volta 574 Grande, Mato Grosso. MSc. Thesis, Fundação Oswaldo Cruz.

575 Lerner BR. 1994. A alimentação e a anemia carencial em adolescentes. PhD. Dissertation, $576 \quad$ Universidade de São Paulo.

577 Lício JS, Fávaro TR, Chaves CR. 2016. Anemia in indigenous women and children in Brazil: 578 a systematic review. Revista de Ciência \& Saúde Coletiva 21:2571-2581. DOI:

$579 \quad 10.1590 / 1413-81232015218.00532015$

580 Lopes RE, Ramos KS, Bressani CC, De Arruda IK. 2006. Anemia and hipovitaminosis in 581 postpartum women seen at the Women's Care Center of the Instituto Materno Infantil Prof. 582 Fernando Figueira, IMIP: a pilot study. Revista Brasileira de Saúde Materno Infantil. 6:S63583 S68. DOI: 10.1590/S1519-38292006000500009.

584 Lucyk JM. 2006. Perfil antropométrico, consumo alimentar e concentração de hemoglobina 585 de gestantes assistidas no Hospital Universitário de Brasília - H.U.B. MSc. Thesis, $586 \quad$ Universidade de Brasília. 
587 Machado EH, De Carli E, Szarfarc SC, Souza JM, Fujimori E, Colli C. 2016. Anemia among

588 pregnant women attending primary healthcare units in the municipality of São Paulo, Brazil:

589 evaluations after the mandatory fortification of wheat and maize flours with iron. Nutritre

590 41:19. DOI: 10.1186/s41110-016-0020-z.

591 Machado IE, Malta DC, Bacal NS, Rosenfeld LG. 2019. Prevalence of anemia in Brazilian

592 adults and elderly. Revista Brasileira de Epidemiologia 22:1-15. DOI: 10.1590/1980-

$593 \quad 549720190008 . s u p 1.2$

594 Magalhães EI, Maia DS, Netto MP, Lamounier JA, Rocha DS. 2018. Prevalence of anemia

595 and determinants of hemoglobin concentration in pregnant women. Cadernos Saúde Coletiva

596 26:384-390. DOI: 10.1590/1414-462X201800040085.

597 Mariath AB, Henn R, De Matos CH, De Lacerda LL, Grillo LP. 2006. Prevalence of anemia

598 and hemoglobin serum levels in adolescents according to sexual maturation stage. Revista

599 Brasileira de Epidemiologia 9:456-461. DOI: 10.1590/S1415-790X2006000400006.

600 Marin FA, Rasera Junior I, Leite CV, De Oliveira MR. 2015. Ferritin in hypertensive and

601 diabetic women before and after bariatric surgery. Nutrición Hospitalaria 31:666-671. DOI:

$602 \quad 10.3305 /$ nh.2015.31.2.7629.

603 Marion M. 2013. Prevalência de anemia e hipotireoidismo em gestantes atendidas no pré-

604 natal do Hospital Universitário de Santa Maria - RS (HUSM). MSc. Thesis, Universidade

605 Federal de Santa Maria.

606 Marques MR, De Oliveira e Silva LM, Pessoa ML, Araújo MA, Moreira-Araújo RS. 2015.

607 Risk and prevalence of anemia among women attending public and private universities.

608 Ecology of Food and Nutrition 54:520-528. DOI: 10.1080/03670244.2015.1037442. 
609 Massucheti L. 2007. Prevalência de anemia em gestantes atendidas na rede pública de saúde 610 do município de Florianópolis - SC. MSc. Thesis, Universidade Federal de Santa Catarina.

611 Miranda VI, Santos IS, Da Silveira MF, Silveira MP, Dal Pizzol TS, Bertoldi AD. 2018.

612 Validity of patient-reported anemia and therapeutic use of iron supplements during

613 pregnancy: 2015 Pelotas (Brazil) birth cohort. Cadernos Saúde Pública 34:e00125517. DOI:

$614 \quad 10.1590 / 0102-311 X 00125517$.

615 Monteiro-Neto A. 2014. [Desigualdades regionais no brasil: características e tendências

616 recentes]. Boletim regional, urbano e ambiental. 9. Available at:

617 http://repositorio.ipea.gov.br/bitstream/11058/5582/1/BRU_n09_desigualdades.pdf

618 Muthayya S, Rah JH, Sugimoto JD, Roos FF, Kraemer K, Black RE. 2013. The global

619 hidden hunger indices and maps: an advocacy tool for action. PLoS One 8:e67860. DOI:

$620 \quad 10.1371 /$ journal.pone.0067860

621 Neves PA. 2018. Estado nutricional de vitamina A na gravidez e associação com desfechos

622 materno-infantis no estudo MINA-Brasil. PhD. Dissertation, Universidade de São Paulo.

623 Niquini RP, Bittencourt SA, Lacerda EM, Saunders C, Leal MC. 2012. Evaluation of the

624 prenatal nutritional care process in seven family health units in the city of Rio de Janeiro.

625 Revista Ciência \& Saúde Coletiva 17:2805-2816. DOI: 10.1590/S1413-81232012001000028.

626 Nyaga VN, Arbyn M, Aerts M. Metaprop: a Stata command to perform meta-analysis of

627 binomial data. Archives of Public Health 72:39. DOI: 10.1186/2049-3258-72-39.

628 Orellana JD, Cunha GM, Santos RV, Coimbra Jr CE, Leite MS. 2011. Prevalence of and

629 factors associated with anemia in indigenous Surui women aged between 15 and 49 years in

630 the Brazilian Amazon. Revista Brasileira de Saúde Materno Infantil 11:153-161. DOI:

$631 \quad 10.1590 /$ S1519-38292011000200006. 
632 Orsolin GL, Molz P, Lana AJ, Seehaber AD, Schlickmann DS, Dos Santos C, Limberger LB, 633 Prá D, Franke SI. 2020. Anemia in gestational diabetes mellitus: implications for genomic 634 instability. Clinical \& Biomedical Research 40:21-26. DOI: 10.22491/2357-9730.91362.

635 Page MJ, Moher D, Bossuyt PM, Boutron I, Hoffman TC, Mulrow CD, Shamseer L, Tetzlaff 636 JM, Akl EA, Brennan SE, Chou R, Glanville J, Grimshaw JM, Hróbjartsson A, Lalu MM, Li 637 T, Loder EW, Mayo-Wilson E, McDonald S, McGuiness LA, Stewart LA, Thomas J, Tricco 638 AC, Welch VA, Whiting P, McKenzie J. 20201. PRISMA 2020 explanation and elaboration: 639 updated guidance and exemplars for reporting systematic reviews. BMJ. 372: n160. DOI: $640 \quad 10.1136 /$ bmj.n160

641 Papa AC, Furlan JP, Pasquelle M, Guazzelli CA, Figueiredo MS, Camano L, Mattar R. 2003. 642 Iron deficiency anemia in pregnant adolescents: comparison between laboratory tests. Revista 643 Brasileira de Ginecologia e Obstetrícia 25:731-738. DOI: 10.1590/S0100-

64472032003001000006.

645 Pereira RC. 1997. Anemia em parturientes da maternidade Prof. Monteiro de Moraes e peso646 ao-nascer: impacto de condicionantes macro e micro-estruturais. MSc. Thesis, Universidade $647 \quad$ Federal de Pernambuco.

648 Pereira SM, Rocha EM, Szarfarc SC, Gallo PR, Bertoli CJ, Leone C. 2019. Family Health 649 Strategy and prevalence of anemia in women in an urban region of high Human 650 Development Index. Journal of Human Growth and Development. 29:410-415. DOI: $651 \quad$ 10.7322/jhgd.v29.9540.

652 Pessoa LS, Saunders C, Belfort GP, Da Silva LB, Veras LS, Esteves AP. 2015. Temporal 653 evolution of anemia prevalence in pregnant adolescents of a public maternity of Rio de 
654 Janeiro. Revista Brasileira de Ginecologia e Obstetrícia 37:208-215. DOI: 10.1590/SO100-

$655 \quad 720320150005321$.

656 Petry N, Olofin I, Hurrel RF, Boy E, Wirth JP, Moursi M, Angel MD, Rohner F. 2016. The

657 proportion of anemia associated with iron deficiency in low, medium, and high human

658 development index countries: a systematic analysis of national surveys. Nutrients 8:693.

659 DOI: $10.3390 /$ nu8110693

660 Pincelli A, Neves PA, Lourenço BH, Corder RM, Malta MB, Sampaio-Silva J, De Souza

661 RM, Cardoso MA, Castro MC, Ferreira MU, For the Mina Brazil Working Group. 2018. The

662 hidden burden of Plasmodium vivax malaria in pregnancy in the Amazon: An Observational

663 Study in Northwestern Brazil. American Journal of Tropical Medicine and Hygiene 99:73-

664 83. DOI: $10.4269 /$ ajtmh.18-0135.

665 Pinho-Pompeu M, Surita FG, Pastore DA, Paulino DS, Pinto e Silva JL. 2017. Anemia in

666 pregnant adolescents: impact of treatment on perinatal outcomes. Journal of Maternal-Fetal

667 and Neonatal Medicine 30:1158-1162. DOI: 10.1080/14767058.2016.1205032.

668 Quintans AM. 2011. Anemia em gestantes: avaliação das usuárias das unidades básicas de 669 saúde do Município de Cabedelo-Paraíba. MSc. Thesis, Universidade Federal da Paraíba.

670 Renz PB. 2018. Hemoglobina glicada (HbA1c) no diabetes mellitus gestacional. PhD.

671 Dissertation, Universidade Federal do Rio Grande do Sul. 2018.

672 Rezende LR. 2007. Anemia em crianças e mães de creches públicas de Natividade

673 (RJ):prevalência, fatores de risco e validade do exame clínico palidez palmar. MSc. Thesis, $674 \quad$ Universidade Federal de Minas Gerais.

675 Rocha DS, Netto MP, Piore SE, De Lima NM, Rosado LE, Frasceschini SC. 2005.

676 Nutritional status and iron-deficiency anemia in pregnant women: relationship with the 
677 weight of the child at birth. Revista de Nutrição 18:481-489. DOI: 10.1590/S1415-

$678 \quad 52732005000400004$.

679 Roncada MJ, Szarfarc SC. 1975. Vitamin A deficiency and iron deficiency anemia in 680 pregnant women of two communities of the Ribeira River Valley (State of S. Paulo, Brazil).

681 Revista de Saúde Pública 9:99-106. DOI: 10.1590/S0034-89101975000200002.

682 Rondó PH, Tomkins AM. 1999. Maternal iron status and intrauterine growth retardation.

683 Transactions of the Royal Society of Tropical Medicine and Hygiene 93:423-426. DOI:

$684 \quad 10.1016 / \mathrm{s} 0035-9203(99) 90144-x$.

685 Sales CH, Rogero MM, Sarti FM, Fisberg RM. 2021. Prevalence and factors associated with 686 iron deficiency and anemia among residents of urban areas of São Paulo, Brazil. Nutrients 687 13:1888. DOI: $10.3390 /$ nu13061888.

688 Santos PN. 2006. Prevalência de anemia nas gestantes atendidas em Unidades de Saúde em 689 Feira de Santana, Bahia, entre outubro de 2005 e março de 2006. MSc. Thesis, Universidade 690 Estadual de Feira de Santana.

691 Santos IS, Minten GC, Valle NC, Tuerlinckx GC, Boccio J, Barrado DA, Da Silva AB, 692 Pereira GA. 2009. Helicobacter pylori and anemia: a community-based cross-sectional study 693 among adults in Southern Brazil. Cadernos de Saúde Pública 25:2653-2660. DOI:

$694 \quad 10.1590 / \mathrm{S} 0102-311 \mathrm{X} 2009001200012$.

695 Santos CL, Akerman M, Faccenda O, Martins LC, Reato LF. 2012. Iron deficiency during 696 pubertal growth spurt. Journal of Human Growth and Development 22:341-347. DOI:

$697 \quad 10.7322 /$ jhgd.46611. 
698 Saunders C, Leal MC, Neves PA, Padilha PC, Da Silva LB, Schilithz AO. 2016.

699 Determinants of gestational night blindness in pregnant women from Rio de Janeiro, Brazil.

$700 \quad$ Public Health Nutrition 19:851-860. DOI: 10.1017/S1368980015001846.

701 Sena de Lira N. 2009. Anemia e fatores associados em mulheres de municípios do Nordeste

702 brasileiro - 2005. MSc. Thesis, Universidade Federal de Pernambuco.

703 Silla LM, Zelmanowicz A, Mito I, Michalowski M, Hellwing T, Shilling MA, Friedrisch JR, 704 Bittar CM, Albrecht CA, Scapinello E, Conti C, Albrecht MA, Baggio L, Pezzi A, Amorin B, 705 Valim V, Fogliatto L, Paz A, Astigarraga C, Bittencourt RI, Fischer G, Daudt L. 2013. High 706 prevalence of anemia in children and adult women in an urban population in Southern Brazil.

$707 \quad$ PLoS One 8:e68805. DOI: 10.1371/journal.pone.0068805.

708 Silva TS, Santos JM, Oliveira FM. 2018. Níveis de hemoglobina e consumo de alimentos 709 fontes de ferro em estudantes do ensino médio. Revista Brasileira de Ciências da Saúde 710 22:307-314. DOI: $10.4034 /$ RBCS.2018.22.04.03.

711 Silva JV, Ferreira RC, Tenório MB, Tenório MC, Silveira JA, Amaral AC, Goulart MO, 712 Moura FA, Oliveira AC. 2020. Hyperferritinemia worsens the perinatal outcomes of 713 conceptions of pregnancies with preeclampsia. Pregnancy Hypertension 19:233-238. DOI:

$714 \quad$ 10.1016/j.preghy.2019.11.004.

715 Silveira VN, Caravalho CA, Viola PC, Magalhães EI, Padilha LL, Conceição SI, Frota MT, 716 Calado IL, Catanhede NA, Franceschini SC, França AK. 2021. Prevalence of iron-deficiency 717 anaemia in Brazilian children under 5 years of age: a systematic review and meta-analysis. 718 British Journal of Nutrition 126:1257-1269. DOI: 10.1017/S000711452000522X

719 Simpson JL, Bailey LB, Pietrzik K, Shane B, Holzgreve W. 2011. Micronutrients and 720 women of reproductive potential: required dietary intake and consequences of dietary 
721 deficiency or excess. Part II--vitamin D, vitamin A, iron, zinc, iodine, essential fatty acids.

722 Journal of Maternal-Fetal and Neonatal Medicine 24:1-24. DOI:

$723 \quad 10.3109 / 14767051003678226$.

724 Sinisterra Rodriguez OT, Szarfarc SC, Benicio MH. 1991. Maternal anemia and

725 undernowrishment and their relation to birth - weight. Revista de Saúde Pública 25:193-197.

726 DOI: $10.1590 /$ S0034-89101991000300006.

727 Szarfarc SC. 1974. Hematological study of pregnant women and newborn children. Revista

728 de Saúde Pública 8:369-374. DOI: 10.1590/S0034-89101974000400003.

729 Szarfarc SC, De Siqueira AA, Martins IS, Tanaka AC. 1982. A comparative study of

730 biochemical indicators of iron concentration in two groups of pregnant women, with and

731 without pre-natal care. Revista de Saúde Pública 16. DOI: 10.1590/S0034-

$732 \quad 89101982000100001$.

733 Szarfarc SC. 1985. Nutritional anaemia in pregnant women attending health centers in S.

734 Paulo State (Brazil). Revista de Saúde Pública 19:450-457. DOI: 10.1590/S0034-

$735 \quad 89101985000500009$.

736 Tapia ME, Faleiro ML, Gontijo ML, Martins CS, Viana KA, Dusse LM, et al. 2010.

737 Prevalence of anemia in pregnant women assisted by the sistema único de saúde: Secretaria

738 Municipal de Saúde: Prefeitura de Belo Horizonte. Revista Brasileira de Análises Clínicas

$739 \quad$ 42:277-281.

740 Walter LB, Dolzan D, Areias T, Bergmann CG, Rizzolli J, Mottin CC, Padoin AV. 2021.

741 Adverse neonatal and obstetric outcomes in a 20-year Brazilian retrospective cohort of

742 pregnancies after bariatric surgery. Obesity Surgery 31:2859-2868. DOI: 10.1007/s11695-

$743 \quad$ 021-05369-y. 
744 World Health Organization. 2001. Iron deficiency anaemia: assessment, prevention, and

745 control: a guide for programme managers. Geneva, World Health Organization. Available at

746 https://www.ihs.org.in/SHG/WHO-Anemia\%20detection\%20guidelines.pdf (accessed 05

747 October 2021).

748 World Health Organization. 2009. Weekly iron-folic acid supplementation (WIFS) in women

749 of reproductive age: Its role in promoting optimal maternal and child health. WHO. Geneva:

$750 \quad$ World Health Organization.

751 World Health Organization. 2011. Haemoglobin concentrations for the diagnosis of anaemia

752 and assessment of severity. Vitamin and Mineral Nutrition Information System. Geneva,

753 World Health Organization.Available at

754 http://www.who.int/vmnis/indicators/haemoglobin.pdf (accessed 02 October 2021)

755 World Health Organization. 2021a. Anaemia. Available at https://www.who.int/health-

756 topics/anaemia\#tab=tab_1 (accessed 02 October 2021)

757 World Health Organization. 2021b. Prevalence of anaemia in women of reproductive age

758 (aged 15-49) (\%). Available at https://www.who.int/data/gho/data/indicators/indicator-

759 details/GHO/prevalence-of-anaemia-in-women-of-reproductive-age-(-

760 )?bookmarkId=1a82123a-9be6-409c-a8c1-5ed9c26f0d85 (accessed 05 October 2021).

761 World Health Organization. 2021c. Prevalence of anaemia in pregnant women (aged 15-49)

762 (\%). Available at https://www.who.int/data/gho/data/indicators/indicator-

763 details/GHO/prevalence-of-anaemia-in-pregnant-women-(-) (accessed 05 October 2021)

764 Zeng X, Zhang Y, Kwong JS, Zhang C, Li S, Sun F, Niu Y, Du L. 2015. The methodological

765 quality assessment tools for preclinical and clinical studies, systematic review and meta- 
766 analysis, and clinical practice guideline: a systematic review. Journal of Evidence-Based

767 Medicine 8:2-10. DOI: 10.1111/jebm.12141. 
Figure 1

Flowchart of study selection 


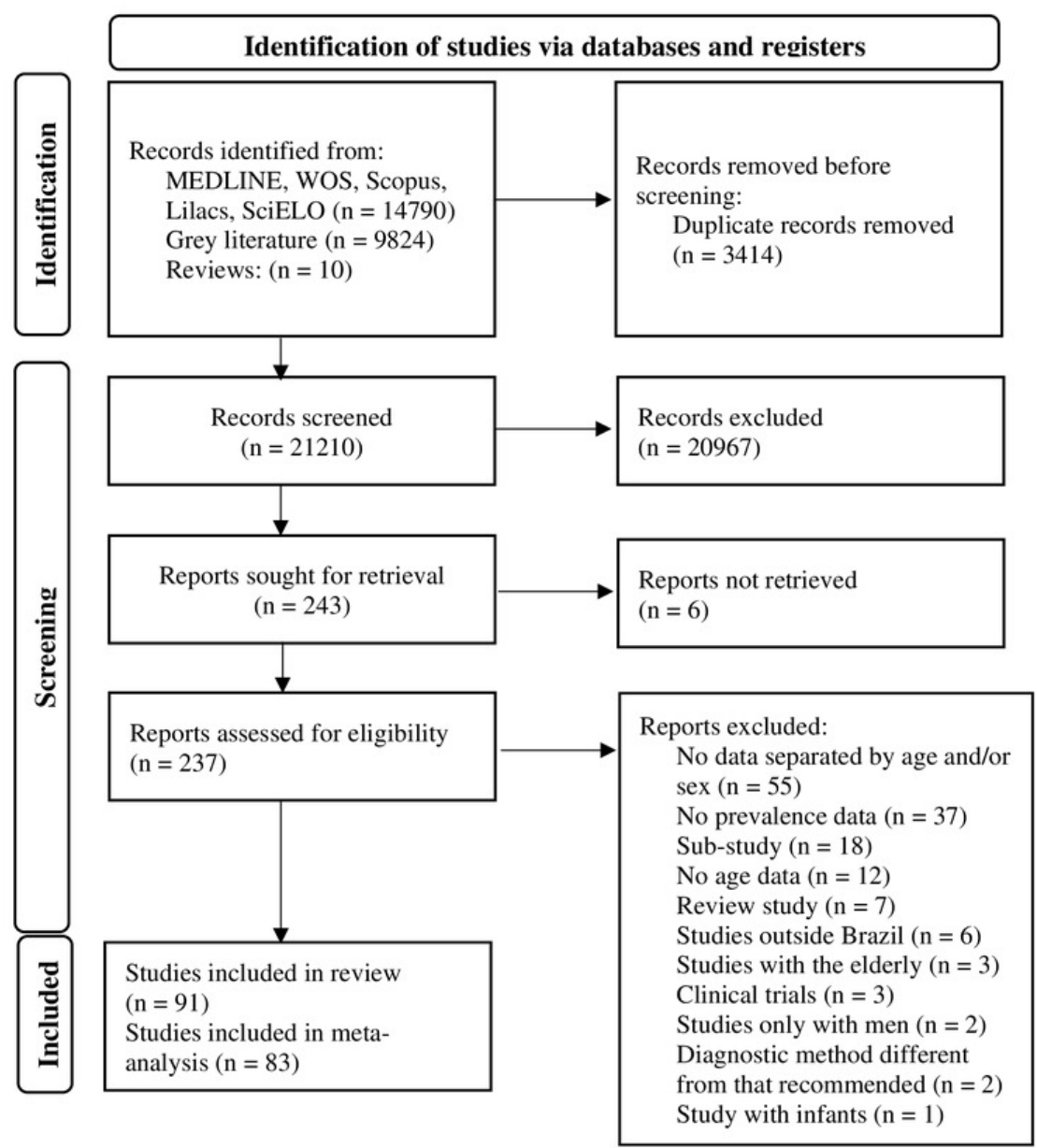

WOS: Web of Science 


\section{Table $\mathbf{1}$ (on next page)}

Summary of the characteristics of the included studies $(n=91)$ 
1 Table 1. Summary of the characteristics of the included studies $(\mathrm{n}=91)$

\begin{tabular}{|c|c|c|}
\hline & $\mathbf{N}$ & $\%$ \\
\hline \multicolumn{3}{|l|}{ Age group } \\
\hline Teenagers & 16 & 17.58 \\
\hline Adults & 17 & 18.68 \\
\hline Teenagers and adults & 48 & 52.75 \\
\hline Not reported & 10 & 10.99 \\
\hline \multicolumn{3}{|l|}{ Pregnancy } \\
\hline Yes & 53 & 58.24 \\
\hline No & 31 & 34.07 \\
\hline Both & 4 & 4.40 \\
\hline Pregnant and non-pregnant separately & 3 & 3.29 \\
\hline \multicolumn{3}{|l|}{ Region } \\
\hline North & 5 & 5.50 \\
\hline Northeast & 26 & 28.57 \\
\hline Midwest & 7 & 7.69 \\
\hline South & 14 & 15.39 \\
\hline Southeast & 34 & 37.36 \\
\hline More than one & 2 & 2.20 \\
\hline All & 3 & 3.29 \\
\hline \multicolumn{3}{|l|}{ Source } \\
\hline Regular paper & 60 & 65.9 \\
\hline Dissertation/theses & 21 & 23.1 \\
\hline Congress abstract & 3 & 3.3 \\
\hline Other sources & 7 & 7.7 \\
\hline \multicolumn{3}{|l|}{ Sampling } \\
\hline Random & 24 & 26.4 \\
\hline Non-random & 67 & 73.6 \\
\hline \multicolumn{3}{|l|}{ Context } \\
\hline Household survey & 15 & 16.48 \\
\hline Hospital & 15 & 16.48 \\
\hline Outpatient/Basic health unit & 39 & 42.86 \\
\hline $\begin{array}{l}\text { School/University/Day care } \\
\text { center/Swim club }\end{array}$ & 12 & 13.19 \\
\hline Indigenous village & 7 & 7.69 \\
\hline Hospital and Outpatient & 1 & 1.10 \\
\hline Not reported & 2 & 2.20 \\
\hline \multicolumn{3}{|l|}{ Measurement method } \\
\hline Hemocue & 24 & 26.37 \\
\hline Cianometahemoglobina & 15 & 16.48 \\
\hline Cell-Dyn & 7 & 7.69 \\
\hline Sysmex & 4 & 4.40 \\
\hline Pentra & 3 & 3.30 \\
\hline Agabe & 3 & 3.30 \\
\hline BC 2800 e BS220 & 1 & 1.09 \\
\hline Coulter & 1 & 1.09 \\
\hline
\end{tabular}


Cell Counter CELLM

Cyanide-free photometry

Medical record

Not reported
1.09

1.09

18.68

15.39

2 


\section{Table 2 (on next page)}

Summary of the results found from the meta-analysis of the prevalence of iron deficiency in Brazilian adolescents and adult women of reproductive age (83 studies included) 
1 Table 2. Summary of the results found from the meta-analysis of the prevalence of iron deficiency in Brazilian adolescents and adult 2 women of reproductive age ( 83 studies included)

\begin{tabular}{|c|c|c|c|c|c|c|c|}
\hline & Studies & $\mathbf{n}$ & $\mathbf{N}$ & Pooled prevalence (\%) & Lower 95\% CI & Upper 95\% CI & $\mathbf{I}^{2}$ \\
\hline Total & 83 & 15075 & 57981 & 25 & 23 & 28 & 97.94 \\
\hline \multicolumn{8}{|l|}{ Region } \\
\hline North & 7 & 1752 & 5328 & 30 & 24 & 37 & 95.35 \\
\hline Northeast & 27 & 5400 & 19087 & 30 & 26 & 34 & 97.02 \\
\hline Midwest & 7 & 518 & 2177 & 24 & 16 & 33 & 95.09 \\
\hline South & 15 & 2343 & 11231 & 20 & 14 & 27 & 98.59 \\
\hline Southeast & 36 & 4944 & 19985 & 21 & 17 & 26 & 98.08 \\
\hline \multicolumn{8}{|l|}{ Age group } \\
\hline Teenagers & 16 & 839 & 3580 & 18 & 11 & 27 & 97.44 \\
\hline Adults & 16 & 2211 & 8091 & 26 & 21 & 31 & 95.93 \\
\hline Both & 42 & 8525 & 33527 & 26 & 22 & 29 & 98.15 \\
\hline \multicolumn{8}{|c|}{ Pregnant women } \\
\hline Yes & 51 & 11475 & 42224 & 26 & 23 & 30 & 98.19 \\
\hline No & 32 & 3334 & 14739 & 22 & 18 & 27 & 97.23 \\
\hline Both & 3 & 266 & 1018 & 42 & 17 & 69 & 96.86 \\
\hline \multicolumn{8}{|c|}{ Year collection } \\
\hline$<2005$ & 23 & 6468 & 22313 & 25 & 21 & 29 & 97.53 \\
\hline $2005-2010$ & 25 & 3673 & 19334 & 25 & 21 & 30 & 97.94 \\
\hline
\end{tabular}




\begin{tabular}{|c|c|c|c|c|c|c|c|}
\hline $2010-2015$ & 16 & 1370 & 5553 & 23 & 16 & 30 & 97.66 \\
\hline$\geq 2015$ & 9 & 2543 & 7291 & 28 & 23 & 34 & 95.18 \\
\hline \multicolumn{8}{|l|}{ Context } \\
\hline Household survey & 13 & 1954 & 8130 & 24 & 20 & 39 & 93.73 \\
\hline Hospital & 13 & 2757 & 7753 & 36 & 31 & 40 & 92.83 \\
\hline $\begin{array}{l}\text { Outpatient/Basic health } \\
\text { unit }\end{array}$ & 40 & 8486 & 35562 & 21 & 18 & 24 & 98.38 \\
\hline $\begin{array}{l}\text { School/University/Day care } \\
\text { center/Swim club }\end{array}$ & 12 & 527 & 2309 & 25 & 14 & 37 & 97.71 \\
\hline Indigenous village & 4 & 305 & 923 & 53 & 27 & 78 & 97.65 \\
\hline \multicolumn{8}{|l|}{ Sampling method } \\
\hline Random & 22 & 2169 & 10059 & 22 & 17 & 27 & 96.95 \\
\hline Non-random & 61 & 8795 & 30646 & 27 & 23 & 30 & 97.99 \\
\hline
\end{tabular}


Table 3 (on next page)

Table 3. Evidence quality assessment 
1 Table 3. Evidence quality assessment

\begin{tabular}{|c|c|c|c|c|c|c|c|c|c|}
\hline \multicolumn{10}{|c|}{ Question: What is the prevalence of iron deficiency in Brazilian women of childbearing age? } \\
\hline \multicolumn{7}{|c|}{ Quality assessment } & \multirow{2}{*}{$\begin{array}{c}\begin{array}{c}\text { Results } \\
\text { summary }\end{array} \\
\begin{array}{c}\text { Pooled } \\
\text { prevalence } \\
(\%)\end{array}\end{array}$} & \multirow[b]{2}{*}{ Quality } & \multirow[b]{2}{*}{$\begin{array}{c}\text { Importanc } \\
\mathrm{e}\end{array}$} \\
\hline $\begin{array}{c}\mathbf{N}^{0} \text { of } \\
\text { studies }\end{array}$ & Study design & $\begin{array}{c}\text { Risk of } \\
\text { bias }\end{array}$ & $\begin{array}{c}\text { Inconsisten } \\
\text { cy }\end{array}$ & $\begin{array}{l}\text { Indirect } \\
\text { evidence }\end{array}$ & $\begin{array}{c}\text { Imprecisio } \\
\text { n }\end{array}$ & $\begin{array}{c}\text { Other } \\
\text { consideratio } \\
\text { ns }\end{array}$ & & & \\
\hline \multicolumn{10}{|c|}{ Prevalence of iron deficiency (rated with: \%) } \\
\hline 83 & $\begin{array}{l}\text { Observation } \\
\text { al studies }\end{array}$ & Serious & $\begin{array}{l}\text { Very } \\
\text { serious }\end{array}$ & N/A & $\mathrm{N} / \mathrm{A}$ & None & $\begin{array}{c}25 \% \\
\text { [95\% CI: } 23 \text {; } \\
28]\end{array}$ & $\begin{array}{l}\oplus \bigcirc \bigcirc \bigcirc \\
\text { Very Low }\end{array}$ & $\begin{array}{c}\text { IMPORTAN } \\
\mathrm{T}\end{array}$ \\
\hline
\end{tabular}

